\title{
MOTIVASI PEMBELAJARAN DARING DALAM MENINGKATKAN PROSES PEMBELAJARAN UNTUK PARA TENAGA PENDIDIK DI SMPN 12 KOTA TANGERANG SELATAN
}

\author{
${ }^{1}$ Alex Kristian Manik, ${ }^{2 *}$ Joko Nugroho, ${ }^{3}$ Asep Zainuddin, ${ }^{4}$ Disa Rosiyanti, \\ ${ }^{5}$ Wita Pebriani \\ Universitas Pamulang Tangerang Selatan, Banten, Indonesia \\ Email : alexmanik28@gmail.com, ${ }^{* k e l i k d j o k o 36 @ g m a i l . c o m, ~}$ \\ asepzain.14@gmail.com, rosiyantidisa@gmail.com, tatafebrianie@gmail.com
}

Manuskrip: Maret -2021; Ditinjau: Maret -2021; Diterima: Mei -2021;

Online: Juli-2021; Diterbitkan: Juli-2021

\begin{abstract}
ABSTRAK
Kegiatan pengabdian kepada masyarakat ini bertujuan untuk memberikan penyuluhan dan berbagi ilmu mengenai proses pembelajaran daring supaya para Tenaga Pendidik khususnya termotivasi dan memiliki strategi dalam memberikan aktivitas pembelajaran yang menarik, positif dan termotivasi untuk para muridnya. Semua aspek kehidupan dari aktivitas bersama keluarga, sekolah dan lingkungan sekitarnya berubah 180 derajat dikarenakan Pandemi Covid-19. Salah satunya yang berubah hampir 360 derajat yaitu pendidikan di sekolah. Kegiatan proses belajar dan mengajar di sekolah dilakukan secara daring atau online, dimana dari dulu hingga sebelum pandemi covid-19 dilakukan secara luring atau offline. Sama halnya dengan Sekolah Menengah Pertama Negeri 12 Tangerang Selatan yang terletak di Jurang Mangu Tangsel yang harus mengikuti perintah dari Kementerian Pendidikan dan Kebudayaan Republik Indonesia bahwa semua seluruh sekolah, kampus, pesantren diharapkan melakukan aktivitas proses pembelajarannya secara daring. Hal ini menjadi tantangan terbaru untuk para Tenaga Pendidik dan Tenaga Kependidikan di Sekolah dan Pendidikan Tinggi.
\end{abstract}

\section{Kata Kunci: Covid 19, Belajar, Daring, SMP 12 Tangsel}

\section{PENDAHULUAN}

Di masa pandemi Covid-19 ini, semua aspek kehidupan berubah menjadi Kebiasaan Baru yang awalnya menurut orang lain tidak biasa, sekarang menjadi sesuatu kebiasaan baru contohnya dengan menggunakan masker setiap ke luar rumah dan harus mencuci tangan dengan air bersih, sabun atau handsanitizer. Hal ini diharuskan untuk terhindar dari virus Covid-19 yang bisa menular secara cepat dari orang ke orang, dari benda ke orang dengan sangat mudah. Oleh karena itu, pemerintah daerah menerapkan Pembatasan Sosial Berskala Besar (PSBB) di beberapa zona merah dan zona hitam. PSBB tujuannya untuk meminimalisir penularan virus Covid-19 dan menurunkan jumlah masyarakat yang sakit dengan membatasi kegiatan di luar rumah.Semua aspek kehidupan dari aktivitas bersama 
keluarga, sekolah dan lingkungan sekitarnya berubah 180 derajat dikarenakan Pandemi Covid-19. Salah satunya yang berubah hampir 360 derajat yaitu pendidikan di sekolah. Kegiatan proses belajar dan mengajar di sekolah dilakukan secara daring atau online, dimana dari dulu hingga sebelum pandemi covid-19 dilakukan secara luring atau offline.

Sama halnya dengan Sekolah Menengah Pertama Negeri 12 Tangerang Selatan yang terletak di Jurang Mangu Tangsel yang harus mengikuti perintah dari Kementerian Pendidikan dan Kebudayaan Republik Indonesia bahwa semua seluruh sekolah, kampus, pesantren diharapkan melakukan aktivitas proses pembelajarannya secara daring. Hal ini menjadi tantangan terbaru untuk para Tenaga Pendidik dan Tenaga Kependidikan di Sekolah dan Pendidikan Tinggi.

Berdasarkan informasi dan data yang kami terima di Sekolah Menengah Pertama Negeri 12 Tangerang Selatan yang terdiri dari 50 tenaga pendidik mereka sudah merasa nyaman dengan proses pembelajaran daring tetapi belum tentu siswa atau muridnya merasa nyaman. Hal ini membuat murid-murid dan orang tua merasa terbebani dengan adanya pembelajaran daring. Ada beberapa orang tua yang merasa bingung untuk membantu anaknya di rumah dalam memberikan pengarahan dalam memahami pembelajaran yang diberikan dari gurunya. Sehingga menuntut orang tua dan murid harus bisa memahami dan belajar menggunakan teknologi digital.

SMPN 12 Tangerang Selatan yang harus bisa memberikan yang terbaik kepada para tenaga pendidik, tenaga kependidikan dan murid serta masyarakat sekitar. Oleh karena itu, harus mendapatkan feedback atas proses pembelajaran yang telah diberikan oleh para pendidik. Dengan adanya pandemi Covid-19 ini membuat para tenaga pendidik memberikan pembelajaran yang bisa memudahkan para murid-muridnya mengerti, memahami dan menyenangkan di semua mata pelajaran.

Ini merupakan tantangan baru untuk para tenaga pendidik dalam menghadapi dan membuat bahan ajar serta memberikan motivasi kepada para muridnya. Untuk itu dibutuhkan motivasi dalam memberikan pembelajaran yang kreatif dan inovatif dalam mentrasnfer ilmu dari tenaga pendidik ke murid dengan cara yang menyenangkan dan tidak terlalu membebankan orang tua dalam membantu anakanaknya di rumah.

\section{METODE PELAKSANAAN}

Melihat permasalahan yang dihadapi maka langkah-langkah yang dilakukan untuk mencapai tujuan dan sasaran kegiatan ini maka berkoordinasi dengan pihak sekolah yang memungkinkan tenaga pendidik bisa ikut dalam pelatihan dan penyuluhan tersebut dari awal sampai akhir. Sehingga bisa sesuai dengan target yang kami inginkan yaitu mengetahui mengenai motivasi pembelajaran secara daring dan menambah khazanah ilmu kewirausahaan. Pelaksanaan ini juga bekerjasama dengan usaha Herbal Penawar Alwahida Indonesia yang merupakan produk Indonesia yang halal dan thoyib dengan modal hanya Rp. 10.000 bisa menjadi pengusaha. Ini memberikan peluang yang sangat besar untuk kemajuan 
ekonomi Indonesia dan menjadikan masyarakat yang cerdas, sehat, banyak saudara dan sejahtera.

\section{HASIL PEMBAHASAN}

Permasalahan mitra dalam pengabdian kepada masyarakat di Sekolah Menengah Pertama Negeri 12 Tangerang Selatan yang terletak di Jurang Mangu Tangerang Selatan. Berdasarkan hasil survei dan observasi serta informasi dari pimpinan yang ada di sana, dengan adanya perubahan metode pembelajaran membuat tenaga pendidik dan peserta didik berubah cara pembelajarannya dari luring menjadi daring. Hal ini membutuhkan pelatihan dan panduan mengenai pembelajaran secara daring. Dari pihak sekolah membutuhkan pelatihan dan panduan serta motivasi untuk para tenaga pendidik dalam memberikan pembelajaran secara daring.

Dengan adanya perubahan metode pembelajaran dari luring ke daring memberikan beberapa kendala yang harus dibantu sehingga capaian pembelajaran dapat tercapai sesuai dengan yang ditentukan. Selain itu kebutuhan masyarakat yang berubah selama masa pandemi Covid-19 ini menjadikan masyarakat harus lebih berhemat, sedangkan untuk metode pembelajaran daring sangat membutuhkan kuota internet dalam pelaksanaannya. Ini menjadikan masalah tersendiri untuk tenaga pendidik, pendidik dan orang tua serta pihak sekolah.

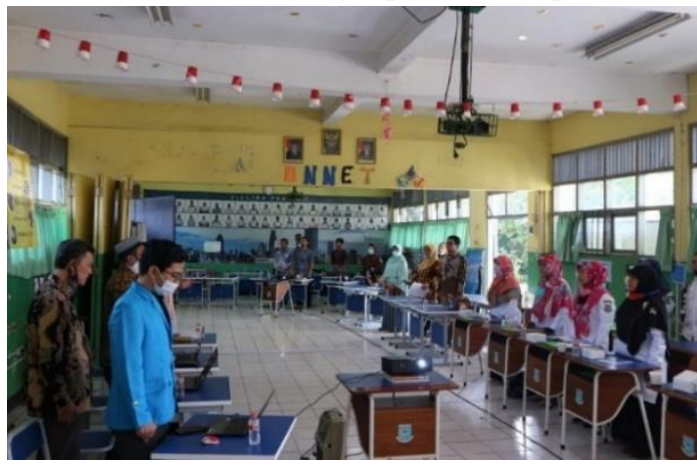

Gambar 1. Doa Bersama

Selain itu, dengan adanya pembelajaran daring menjadikan murid-murid stand by di depan komputer atau handphone.

Dengan banyaknya perubahan dan tuntutan hidup dikarenakan Pandemi Covid-19 ini menjadikan orang tua dan pendidik harus lebih kratif dan inovatif dalam mendapatkan penghasilan serta pembelajaran. Selain memberikan motivasi dalam pembelajaran daring, yang dibutuhkan adalah adanya pelatihan kewirausahaan untuk para pendidik. Hal ini untuk memfasilitasi dan memotivasi tenaga pendidik untuk memberikan implementasi dalam ilmu kewirausahaan. Jadi dengan Bekerja Di Rumah (BDR) bisa sambil mengajar, bekerja dan berwirausaha.

Kewirausahaan bisa dengan modal yang kecil atau tanpa modal bisa dilakukan dengan keinginan yang kuat dan fokus serta dibutuhkan networking atau kerjasama dengan berbagai pihak.

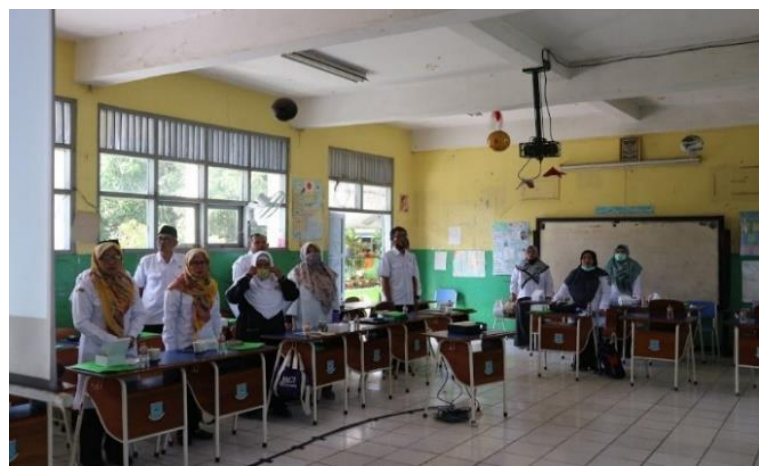

Gambar 2. Diskusi Bersama Siswa 
Hal ini dibutuhkan karena dengan adanya kerjasama dan kolaborasi dengan berbagai pihak memudahkan kita untuk memasarkan atau membuat market place tersendiri dengan meningkatkan perekonomian masyarakat sekitarnya, Dari kita oleh kita dan untuk kita, jadi Indonesia terbebas dari riba, hutang dan impor. apabila bangsa kita bisa membuat produk yang lebih unggul dan terjamin kualitasnya maka negara lain bisa mengekspor dari Indonesia, dan semakin sejahtera rakyat Indonesia.

Jadi dimulai dari SMP bisa mengajarkan murid-murid serta tenaga pendidik untuk memulai usaha dan bisni seperti negara tetangga yaitu Singapura. Mereka bisa sukses karena dari kecil sudah diajarkan untuk berwirausaha dan bekerjasama. Zaman sekarang tanpa kerjasama dan kolaborasi sangat sulit untuk membuka suatu usaha dan bisnis. Oleh karena itu, dibutuhkan kerjasama yang baik win win solution dan saling menguntungkan dan tidak sikut-sikutan.

\section{KESIMPULAN DAN SARAN}

Motivasi belajar merupakan segala dorongan yang mampu memberikan energi dan semangat untuk melakukan tindakan belajar demi mencapai arah dan tujuan yang diinginkan. Sedangkan motivasi ekstrinsik dapat dilihat dari adanya penghargaan dalam belajar, kegiatan yang menarik dalam belajar dan lingkungan belajar yang kondusif. Dengan berbagai kelebihan yang ditawarkan, e-learning merupakan salah satu media pembelajaran yang dapat digunakan untuk memotivasi peserta didik.

E-learning merupakan pembelajaran yang menggunakan fasilitas kecanggihan TIK yang memberikan kemudahan bagi pengguna untuk belajar mandiri, dimana saja, kapan saja, sehingga mendorong mereka senang belajar dan berupaya meningkatkan kompetensi belajarnya.

Proses pembelajaran dengan menggunakan e-learning hendaknya tidak menempatkan peserta didik hanya sebagai "pendengar" atau "penonton" saja,

\section{DAFTAR PUSTAKA}

Affandi, A., et al (2020). Optimization of MSMEs Empowerment in Facing Competition in the Global Market during the COVID-19 Pandemic Time. Systematic Reviews in Pharmacy, 11(11), 1506-1515.

Firman \& Sari. (2020). Pembelajaran Online di Tengah Pandemi Covid-19. Indonesian Journal Of Educational Science (IJES), Volume 02 No 02.

Keputusan Presiden Republik IndonesiaNomor 11 tahun 2020 Tentang Penetapan Kedaruratan Kesehatan Masyarakat Corona Virus Disease 2019 (Covid- 19); Nurjaya, N., et al (2020). Edupreneurship management in shaping the nation's character. Jurnal Konseling dan Pendidikan, 8(3), 198-206.

Pasal 4 ayat (1) Undang-Undang Dasar Negara Republik Indonesia Tahun 1945; Peraturan Gubernur Nomor 27 Tahun 2020 tentang Pedoman PSBB

Peraturan Menteri Pendidikan Dan Kebudayaan Republik Indonesia Nomor 3 tahun 2020 Tentang Standar Nasional Pendidikan Tinggi; 
Peraturan Menteri Pendidikan Dan Kebudayaan Republik Indonesia Nomor 7 Tahun 2020 Tentang Pendirian, Perubahan, Pembubaran Perguruan Tinggi Negeri, Dan Pendirian, Perubahan, Pencabutan Izin Perguruan Tinggi Swasta;

Peraturan Pemerintah Republik Indonesia Nomor 21 tahun 2020 Tentang Pembatasan Sosial Berskala Besar Dalam Rangka Percepatan Penanganan Corona Virus Disease 2019 (Covid-19);

Sulastri, L., et al (2020). The Role of Decision Support System and Risk Management Using Social Media Promotion. International Journal of Psychosocial Rehabilitation, 24(1).

Sunarsi, D., et al. (2020). Covid-19 Pandemic Analysis Toward Productivity Giving Layoffs Effect in The Company of Industrial Sector around South Tangerang. Prosiding ICoISSE, 1(1), 472-481.

Surat Edaran dari Menteri Pendidikan dan Kebudayaan Nomor: 36962/MPK.A/HK/2020 tertanggal 17 Maret 2020 tentang Pembelajaran secara Daring dan Bekerja dari Rumah dalam rangka Pencegahan Penyebaran Corona Virus Disease (Covid-19);

Surat Edaran Nomor 2 Tahun 2020 tentang Pencegahan dan Penanganan COVID19 di Lingkungan Kemendikbud;

Surat Edaran Nomor 3 Tahun 2020 tentang Pencegahan COVID-19 pada Satuan Pendidikan;

Surat Edaran Nomor: 302/E.E2/KR/2020 tentang Masa Belajar Penyelenggaraan Pendidikan;

Surat Keputusan Menteri Kesehatan Nomor HK.01.07 /Menkes/239/2020, tentang Penetapan Pembatasan Sosial Berskala Besar di Wilayah Provinsi DKI Jakarta Dalam Rangka Percepatan Penanganan Corona Virus Disease 2019 (COVID 19);

UU No. 6 Tahun 2018 tentang Karantina Kesehatan (Lembaran Negara Republik Indonesia Tahun 2018 Nomor 128, Tambahan Lembaran Negara Republik Indonesia Nomor 6236);

Yuangga, K. D., \& Sunarsi, D. (2020). Pengembangan media dan strategi pembelajaran untuk mengatasi permasalahan pembelajaran jarak jauh di pandemi covid-19. JGK (Jurnal Guru Kita), 4(3), 51-58.

Yulistiana, I., et al (2021). Did Brand Perceived Quality, Image Product And Place Convenience Influence Customer Loyalty Through Unique Value Proposition?. Journal of Contemporary Issues in Business and Government, 27(1), 2854-2867. 